\title{
Promoting Sustainable Life through Education for Sustainable Development (ESD) and Religious Education
}

\author{
Sari Okta Fiana1, Fahrurrazi², \\ Centre for Research on Peace and Development (CRPD), Faculty of Social Sciences, \\ Leuven University (KU Leuven) ${ }^{1}$ \\ Centre for International Language and Cross Cultural Studies (CILACS), Universitas \\ Islam Indonesia ${ }^{2}$ \\ sarioktafiana@gmail.com ${ }^{1}$ \\ fahrur.elrazi@gmail.com ${ }^{2}$
}

\begin{abstract}
Article History:
First Received:

$29 / 05 / 2020$

Final Revision:

$27 / 06 / 2020$

Available online:

$30 / 06 / 2020$

Abstract. This paper aims to scrutinize how Indonesian religious education, particularly the 2013 curriculum of junior high schools (7-9-year-old), has addressed environmental issues in its concepts or practices. In the Indonesian context, Education for Sustainable Development (ESD) has been implemented since 2009, and it ideally should be integrative in the curriculum. Religious education as the core of the national curriculum has pivotal roles in guiding students on how to be good people. In line with the ESD vision in preserving this Earth, a religious education curriculum has visions similar to the ESD. Therefore, this research reviewed the religious education curriculum literature and conducted an in-depth interview with five religious education teachers. Its results conveyed that the ESD values have existed within the religious education curriculum. However, practically it is less effective because the curriculum tends to focus on cognitive goals. In addition, more training is necessary to increase teachers' capacity.
\end{abstract}

Keywords: Education for Sustainable Development (ESD), Religious Education, Religion, Curriculum

\section{http://jos.unsoed.ac.id/index.php/ies}

\section{INTRODUCTION}

According to livescience.com, the Earth's average temperature has risen between 0.4 and $0.8{ }^{\circ} \mathrm{C}$ over the past 100 years. Increased volumes of carbon dioxide and other greenhouse gases are released by burning fossil fuels, land clearing, agriculture, and other human activities. Ecosystem assessment of Millennium reports that biodiversity has suffered significant losses because around $10-30 \%$ of mammal, bird, and amphibian species are threatened by extinction due to human actions. 
To address our ecological crisis, education as a social agent has played significant roles through Education for Sustainable Development (ESD) that has been initiated by UNESCO to solve our ecological problems. The ESD has been implemented in Indonesia since 2009, but previously since 1986 the Indonesian government has initiated environmental education existing until today with a program, namely "green school".

Religion is important for Indonesians. According to the World Value Survey 2015, it was reported that religion is very important to Indonesian's life. Hence, religious education must be taught in Indonesian schools. Officially, there are six recognized religions, so each student must get religious lessons based on their religion. The national curriculum has set that religious education is the core of the curriculum.

\section{REASEARCH METHOD}

By using a qualitative approach and a literature study technique, this paper questions how the Indonesian curriculum of religious education has addressed the ecological crisis both ideas and practices and how the curriculum relates to the ESD concept. The curriculum explored is the 2013 curriculum especially in the level of junior high schools (7-9 years old). To obtain the data, particularly the practices, indepth interviews with five religious education teachers and Indonesian experts in the ESD were conducted. To analyze the data, the author employed some steps such as data reduction, data display, and conclusion/verification (Miles and Huberman cited in Punch, 2009).

\section{CONTEXT AND CONCEPT}

According to UNESCO, ESD empowers everyone to make decisions based on information for environmental integrity, economic viability, and just society for present and future generations, while respecting cultural diversity (UNESCO, 213). Historically, the context of the ESD link to the United Nations Conference on Environment and Development (UNCED) in which 178 Member States agreed to the framework for action in Agenda 21 - chapter 36, recognizes that education, training, and public awareness are essential tools for transition for sustainable development. It called for a reorientation of education towards sustainable development' (UN, 1992: paragraph 36).

UNESCO was assigned as a task manager for chapter 36. Parallel articles between the three Rio Conventions (UN Framework Convention on Climate Change [UNFCCC], UN Convention on Biological Diversity [UNCBD], and the UN Convention to Combat Desertification [UNCCD]), and programs UNESCO are approved by the Member States. Principles Agenda 21 and the underlying framework continue to guide conceptual thinking and planning for ESD, from the global level to regional actions and Local Agenda 21 initiatives. (UNESCO, 2014: 16)

In the global agenda, UNESCO promotes the ESD within an international system approved by its member. Started in 2005, UNESCO initiated Decade of Education for Sustainable Development (DESD) which had ended in 2015. To broaden the ESD concept, ESD implementation has been applied at all levels of education and various types of education, whether it is formal, informal and non-formal education, vocational education, work-place training, higher education, or adult learning as a part of the learning throughout life. 
Sustainable development issues are integrated into teaching and learning. These include themes such as climate change, disaster risk mitigation, sustainable livelihoods, sustainable consumption and production, biodiversity, and poverty reduction. Because these problems are characterized by uncertainty, complexity, and a high level of systemic interconnection, ESD requires participatory teaching and learning methods such as thinking critically, imagining future scenarios, and jointly making decisions to empower students to take action for sustainable development. (UNESCO, 2014: 20)

According to UNESCO, seven key concepts of ESD frame the ESD perspective from ideas into practice. Concepts such as citizenship and governance, sustainable change, the needs and rights of future generations, interdependence, diversity, uncertainty, and preventive actions, quality of life, equality, and justice.

In Indonesian context, since 2009 the ESD has been applied in many schools both formal and nonformal. Its implementations are integrated within the Indonesian curriculum. The integration of the curriculum is by enriching and developing the curriculum including ecological issues by using three approaches: economy, socialculture, and ecology. In addition, the Indonesian curriculum has been arranged based on regulations published by the educational ministry.

Standard of competence is a primary guidance of how to develop the curriculum through its syllabus and lesson plan. As the core of the curriculum, religious education has a pivotal role in Indonesia. It has the responsibility to shape public and individual morality. In current situation of environmental degradation, religious education can contribute to addressing the problems. Ideally, there is no gap between the ideas and practices because the curriculum has goals in both cognitive skills and attitudes.

\section{RESULT AND DISCUSSION}

\section{THEOLOGICAL CONCEPTS AND ESD VALUES}

According to Stien, an Indonesian expert of ESD, normative bases (theological concepts) of the ESD exists in all religions. Values, principles, ethics, and moral precepts on how to relate with, preserve and maintain the nature have been taught in every religion. In addition, Aulia, an Indonesian expert of ESD, stated that the concepts of the ESD actually are not a new thing. All values and principles of the ESD have existed in all religions like Islam, Catholicism, Christian, Buddhism, Hinduism, and Confucianism. Truly, religions have taught human how to treat nature wisely. Benefitting the nature, we can fulfill our needs, but we cannot use the nature in excessive ways for the greediness of ourselves.

Based on interviews conducted in this research, according to the Islamic teacher, a mandate for human beings is to be rohmatanlil'alamin / actualizing God's blessing for the entire as it has been conveyed in Qu'ran, Surah Al-Baqarah verses 30. The spirit of Islam is Khalifa meaning a human being must preserve and maintain the nature or the environment. Moreover, the teacher explained that the ESD values mostly have already existed in the course syllabus for junior high schools.

Similar to the Islamic teacher, the Christian and Catholic teachers explained that the values and theological concepts of ESD have existed in the course syllabus for the junior high schools. The teachers emphasized that how Christian values have been taught by God's representative (Citra Illahi) to relate with others, to respect 
the universe and to preserve nature. The Buddhist teacher also mentioned the course syllabus of curriculum 2013 has a framework of Buddhism teachings. The Buddhism framework in the junior high schools has similar values with the ESD concepts. Buddha, as a role model, has been shown in how to relate and respect the people, nature, and the universe. The eightfold paths and Buddhism teachings (sila and dharma) have existed in the syllabus.

In addition, the Hinduism teacher stated that the goals of Hinduism teachings in junior high schools firstly to develop and increase student's spirituality and religiosity. It can be seen through the quality of Sradha and Bhakti should be practiced in everyday life. Another goal is to develop the embodiment of Moksartham Jagathita's values in everyday life.

To present the detail of the religious education's ideas and the ESD values, the table below points out the matriculation of standards of competence in religious education and the ESD concepts.

Table 1. Matriculation of the 2013 Curriculum of Religious Education in Six Religions at Junior High School (Year 7-9) and the ESD concepts.

\begin{tabular}{|c|c|}
\hline $\begin{array}{l}\text { Religion } \\
\text { Subject }\end{array}$ & Competence Standard \\
\hline Islam & $\begin{array}{l}\text { 1. (Aqidah) Increasing faith and } \\
\text { spirituality to Allah through } \\
\text { understanding His characteristics. } \\
\text { 2. Understanding of Asmaul Husna. } \\
\text { 3. (Akhlak) Accustoming to positive } \\
\text { behavior. } \\
\text { 4. (Tarikh and Culture of Islam) } \\
\text { Understanding of the Prophet of } \\
\text { Muhammad's history. } \\
\text { 5. (Hadits) Understanding of traditions } \\
\text { of the Prophet Muhammad. } \\
\text { 6. (Akhlak) Preventing of negative } \\
\text { behavior. } \\
\text { 7. (Tarikh and the Culture of Islam): } \\
\text { Understanding history of Islam } \\
\text { diffusion in Indonesia \& respecting } \\
\text { traditions of Islam-Nusantara. }\end{array}$ \\
\hline
\end{tabular}
ESD Concept

Citizenship and stewardship Quality of life, equity and justice Needs and rights of future generations Interdependence Diversity
1. Allah of Trinity and His creation.

2. Explaining of God's creation and His preservation and creativity to save man and all His creatures.

3. Christian's Values: Being grateful in all situations as an embodiment of living in faith and hope.

4. Being responsible for ourselves, others, church, and society.
Citizenship and stewardship Quality of life, equity and justice Needs and rights of future generations Interdependence Diversity 


\begin{tabular}{|c|c|c|c|}
\hline Catholicism & 1. & $\begin{array}{l}\text { Understanding of self-personality as } \\
\text { man and woman in all limitation and } \\
\text { diversity to relate with others and } \\
\text { the environment. } \\
\text { Understanding of Christ and His } \\
\text { efforts struggling as a role model } \\
\text { and spirit to embody His values in } \\
\text { everyday life in the church } \\
\text { community and society. } \\
\text { Understanding of Catholic values to } \\
\text { develop a better future life. }\end{array}$ & $\begin{array}{l}\text { Citizenship and stewardship } \\
\text { Quality of life, equity and justice } \\
\text { Needs and rights of future } \\
\text { generations } \\
\text { Interdependence } \\
\text { Diversity }\end{array}$ \\
\hline Hinduism & $\begin{array}{l}1 . \\
2 .\end{array}$ & $\begin{array}{l}\text { (Sradha) Being convinced about God } \\
\text { as the leader of the universe. } \\
\text { Understanding of Hindu teachings } \\
\text { according to Susila leadership. } \\
\text { Understanding of Sad Atatayi as } \\
\text { personal aspects that must be } \\
\text { prevented. } \\
\text { Understanding of Sapta Timira as } \\
\text { personal aspect that must be } \\
\text { prevented. }\end{array}$ & $\begin{array}{l}\text { Citizenship and stewardship } \\
\text { Quality of life, equity and justice } \\
\text { Needs and rights of future } \\
\text { generations } \\
\text { Interdependence } \\
\text { Diversity }\end{array}$ \\
\hline Buddhism & $\begin{array}{l}4 . \\
5 .\end{array}$ & $\begin{array}{l}\text { Constructing behavior as a Buddhist } \\
\text { as embodiment of a human being } \\
\text { according to Pancadharma. } \\
\text { Developing of virtuous values and } \\
\text { characters in everyday life. } \\
\text { Constructing a good relationship } \\
\text { among community and the } \\
\text { environment. } \\
\text { Constructing positive mentality and } \\
\text { personality. } \\
\text { Understanding and expressing of } \\
\text { Buddhism teaching in developing } \\
\text { human dignity and pride. }\end{array}$ & $\begin{array}{l}\text { Citizenship and stewardship } \\
\text { Quality of life, equity and justice } \\
\text { Needs and rights of future } \\
\text { generations } \\
\text { Interdependence } \\
\text { Diversity }\end{array}$ \\
\hline Confucianism & 1. & $\begin{array}{l}\text { Believing and understanding the } \\
\text { Prophet Kongzi as Mu Duo Tian } \\
\text { (Tian Zi) and understanding } \\
\text { Believing and } \\
\text { Principal Faith in Confucianism } \\
\text { (Cheng Xin Zhi Zhi) } \\
\text { Believing and understanding places } \\
\text { of worshipping of Confucians as a } \\
\text { holy place to develop virtues. } \\
\text { Believing and practicing Prophet } \\
\text { Kongzi's exemplary qualities of } \\
\text { being cautious, serious, humble, } \\
\text { modest and relentless }\end{array}$ & $\begin{array}{l}\text { Citizenship and stewardship } \\
\text { Quality of life, equity and justice } \\
\text { Needs and rights of future } \\
\text { generations } \\
\text { Interdependence } \\
\text { Diversity }\end{array}$ \\
\hline
\end{tabular}

(Source: The 2013 curriculum of religious education competencies of junior high schools) 
Analyzing the 2013 religious education curriculum, mostly the standards of competence of all religious education have related and matched with the ESD concepts. The curriculum has been theologically rooted in line with the ESD concepts of how to relate with others, the universe and how to treat the environment or nature. The framework of the curriculum has taught how to be a good man and to be a representative of God in maintaining the universe. In this sense, the standards of competence in the national curriculum have addressed the ESD concepts.

The next challenge is how teachers practice of these ideas into practices. The teachers' understanding of religion and ecology depends on the teacher's vision, sensitivity, and school's vision. To understand the position of religion and ecology, Bauman (2010: 26) has noted that religion can have various meanings. Nevertheless, we understand and frame that religion is a major force in shaping how we interact with our environment, and it is continually reshaped by new encounters with the nonhuman world.

\section{PRACTICES AND CHALLENGES}

According to Tillich (2010), the study of religion is not primarily about doctrines or rituals per se, but also about whatever a person or a community considers about being her tacit or explicit concern (Bauman, 2010; 28). The students or humans, in general, should take apart to solve ecological crises because their actions as a part of their moralities to interpret and embody their religious values.

Related with the practice of ESD concepts in religious education for junior high school, Stien explained that the integration of religious education and the ESD is less practices and action. For Stein, this occurs because of less training for religious teachers. Thus, it impacts the less practice of the integration of the religious concepts and the ESD concepts.

Also, Aulia explained that the ways of religious education teachers usually do not elaborate on some contextual issues from the idea into the practice. Until now, several teachers have understood the ESD concepts, but the integration of the ESD concept is only written on a paper or an administration document.

Based on interviews with the religious teachers, the five teachers explained that they understood the theme of the teaching and its contextual issues. However, some of them have not yet understood the integration of ESD concepts. If some of them have understood, the practice remains less. Their teaching is not integrative with the ESD concepts.

Based on Maik and Hoffmann (2013), ESD firstly requires a different and more constructive focus on teaching. Teachers must gain insight through constructivism that gaining competence is an independent and active process that can be fostered but not created. Secondly, vision and creating new perspectives are essential tasks because the transformative role of education is a key issue in ESD. Action will change as a product of reflection and vision. Such future actions will consider reflection on what has happened, and use this as a means to imagine a transformation that will create new solutions and ideas. Thirdly, ESD, as a common concern, must be realized in an interdisciplinary team. No one can do ESD alone, this is a collective effort, and everyone brings their strengths and weaknesses to the project. Networking with other partners inside and outside the school is also needed to create a learning 
environment with a continuous spiral that contains vision, planning, action, and reflection. ESD concerns real-life problems and problems and requires the creation of learning opportunities in the community. (Maik and Hoffmann, 2013; 11-12).

To sum up, from all the interviews and explanations, according to Maik and Hoffmann (2013), sensitivity is needed from the teachers themselves to develop their capacity, pedagogy, and professional development in engaging contextual issues. The idea of ESD should teach and engage sustainability for the student by not separating the ESD and religious values.

\section{CONCLUSION}

There are many significant results of the ESD since its implementation in some countries. Since a decade of ESD has been launched by UNESCO in 2005, some targets like the policy, the program, teachers, school, and student's perspectives are to equip and to take action in lively sustainable ways.

In school contexts, the practice of the ESD has some challenges regarding some school policies, teacher capacity, staff, students, and also parents. The concepts of the national curriculum have been matched with the ESD concepts but it has less application and practice in responding to contextual issues. The challenges are dogmatic teaching and less practices. Teacher training is needed to develop teacher capacity to make the integration of religious values and the ESD concepts broader in both cognitive skills and practices.

\section{ACKNOWLEDGMENTS}

The authors thank to Dr. Zainal Abidin Bagir who has guided us to study Religion, Ecology, and Science in the Center for Religious and Cross-cultural Studies (CRCS), the Graduate School, Gadjah Mada University, Yogyakarta Indonesia. A great thank is also dedicated to Ms. Stien Matakupan, Ms. Aulia Wijiasih, and all the religious education teachers who supported this research.

\section{REFERENCES}

Grady, J. S., Her, M., Moreno, G., Perez, C., \& Yelinek, J. (2019). Emotions in storybooks: A comparison of storybooks that represent ethnic and racial groups in the United States. Psychology of Popular Media Culture, 8(3), 207-217.

Adomßent, Maik, and H. Thomas. (2013). The concept of competencies in the context of education for sustainable development (ESD). Concept-Paper-ESDCompetencies.

Bauman, Whitney, Richard Bohannon, and Kevin O'Brien, eds. (2010). Grounding religion: A field guide to the study of religion and ecology. Routledge.

Buckler, Carolee, and Heather Creech. (2014). Shaping the future we want: UN Decade of Education for Sustainable Development; final report. UNESCO.

de Haan, Gerhard, Inka Bormann, and Alexander Leicht. (2010) Introduction: The midway point of the UN Decade of Education for Sustainable Development: Current research and practice in ESD. International Review of Education (56.2-3), 199-206.

Hill, Linda D. (2010). Forging Inclusive Solutions Experiential Earth Charter Education. Journal of Education for Sustainable Development (4.2), 243-251. 
McKeown, Rosalyn, et al. (2002). Education for sustainable development toolkit. Knoxville: Energy, Environment and Resources Center, University of Tennessee.

Michalos, Alex C., et al. (2011). Knowledge, attitudes and behaviours. Concerning education for sustainable development: Two exploratory studies. Social Indicators Research (100.3), 391-413.

Nasional, Departemen Pendidikan. (2006). Pelaksanaan Standar isi dan Standar kompetensi Kelulusan.

Oktafiana, Sari. (2010). Laporan Penelitian Tindakan Kelas "Mengasah Kepekaan Siswa Terhadap Persoalan Lingkungan Pada Mata Pelajaran Ilmu Pengetahuan Sosial (IPS) di Tingkat Sekolah MenengahStudi Kasus Pembelajaran di Kelas 10 Middle Years Program (MYP) International Baccalaureate (IB School) di Sekolah Ciputra Highschool Surabaya.

Pendidikan, Badan Standar Nasional. (2006). Panduan Penyusunan Kurikulum Tingkat Satuan Pendidikan Jenjang Pendidikan Dasar dan Menengah.

Pigozzi, Mary Joy. (2010). Implementing the UN Decade of Education for Sustainable Development (DESD): achievements, open questions and strategies for the way forward. International Review of Education (56.2-3), 255-269.

\section{Websites:}

http://www.globalissues.org

http://www.livescience.com

http://www.worldvaluessurvey.org

Interview with:

Ms. Stien Matakupan (ESD expert)

Ms. Aulia Wijiasih (ESD expert)

Religious education teachers in SMP Tumbuh Yogyakarta 